\title{
Growth of pitaya seedlings according to the type of substrate and the frequency of irrigation
}

\author{
Rodrigo Rafael da Cunha Guimarães ${ }^{1}$, Jonathas de Oliveira Barradas ${ }^{1}$, Raimundo Thiago Lima da Silva ${ }^{1}$, Wendel \\ Kaian Oliveira Moreira ${ }^{2 * \mathbb{D}}$, Samara Ketely Almeida de Souza ${ }^{3}$
}

$10.1590 / 0034-737 X 202168040004$

\begin{abstract}
The objective of this study was to evaluate the development of pitaya cuttings in different substrates under different frequencies of irrigation. The experiment was conducted from January to May 2017 in a greenhouse at the Universidade Federal Rural da Amazônia, Capitão Poço, Pará, Brazil. A completely randomized $3 \times 7$ factorial design with four replicates was used. Pitaya plants were grown from cuttings in three types of substrates (S1: potting soil; S2: potting soil + cattle manure + wood shavings; and S3: washed sand) under seven irrigation frequencies $(24,48,72,96$, 120,144 , and $168 \mathrm{~h}$ ). There was interaction between treatments for root dry matter production, root length variables, the other variables showed no interaction between treatments. The greater development of new and vigorous tissues of the aerial part, the substrates with composition black earth and black earth + manure + sawdust are indicated, and the adoption of the irrigation frequency of $72 \mathrm{~h}$ or $96 \mathrm{~h}$. The use of substrate based on black earth + manure + sawdust, allows savings in the rational use of water and energy with the application of the $96 \mathrm{~h}$ irrigation frequencies, maintaining satisfactory levels of development to the plant. The washed sand substrate can be used for propagation when this material is abundant, however, greater attention should be paid to the supply of water and nutrients to the plant. Keywords: dragon fruit; Hylocereus costaricensis (FACWeber) Britton \& Rose 1909; irrigation interval; root length.
\end{abstract}

\section{INTRODUCTION}

Pitayas or "dragon fruits" belong to the family Cactaceae and are native to the tropical forests of Mexico, Central America, and South America (Mizrahi et al. 1996). In Brazil, pitaya has been introduced recently and since then, it has shown great potential as a fruit crop, particularly the species Hylocereus undatus (white-fleshed red pitaya) and Hylocereus costaricensis (red-fleshed purple pitaya) (Junqueira et al. 2010). Pitaya has high yields (up to $34 \mathrm{t}$ $\mathrm{ha}^{-1}$ ), and it is ready for harvest in the first year of production. Moreover, it has high-value crop for niche markets, which attracts the attention of farmers (Nerd et al. 2002; Le Bellec et al. 2006; Moreira et al. 2018).

To supply the expanding domestic and global markets, the production of pitaya cuttings has been being adapted to large-scale systems, and protocols have been developed to ensure the quality of the fruit crop. In a commercial context, the plants are mainly propagated from cutting, whereas breeding programs use sexual propagation for genetic variation (Silva et al. 2006). According to Galvão et al. (2016), the substrate is the most important factor for a successful rooting of the plant cuttings. Cladodes (photosynthetic shoots) respond well to soil organic matter but develop extensive root systems in sand (Mizrahi \& Nerd, 1999). Thus, a mixture of sand and a substrate rich in organic matter (such as composted cattle manure) is most suitable for obtaining strong, highquality plants from cuttings (Silva et al. 2006; Santos et al. 2010a).

Like other cacti, pitayas are highly adaptable to new environments because of their ability to tolerate abiotic stresses, such as drought and temperature variations. The presence of water-storage tissue (succulence) and a wax layer on the stems, the absence of leaves, nocturnal

\footnotetext{
Submitted on August 19 $9^{\text {th }}, 2020$ and accepted on January 13 $3^{\text {th }}, 2021$.

${ }^{1}$ Universidade Federal Rural da Amazônia, Instituto de Ciências Agrárias, Capitão Poço, Pará, Brazil. rodrigo.guimaraes.1@hotmail.com; jonathas.agronomo@gmail.com; raimundo.lima@ufra.edu.br

${ }^{2}$ Universidade Estadual do Oeste do Paraná, Centro de Ciências Exatas e Tecnológicas, Cascavel, Paraná, Brazil. wendelmoreira21@outlook.com

${ }^{3}$ Universidade Federal Rural da Amazônia, Instituto de Ciências Agrárias, Belém, Pará, Brazil. samarasousa664@gmail.com

*Corresponding author: wendelmoreira21@outlook.com
} 
stomatal conductance, and Crassulacean acid metabolism (CAM) are some characteristics that allow the species to adapt to diverse climatic conditions (Nie et al. 2015). Although pitaya has low water requirement, regular irrigation is needed for high yields. Studies have shown that other fruits that perform CAM photosynthesis respond positively to irrigation (Almeida et al. 2002; Melo et al. 2006). Relevant information on pitaya's tolerance to excess water and optimum frequency of water supply can be achieved by subjecting the plant to different water availability conditions (Moreira et al. 2018).

There is still little knowledge about the best methods of propagating the pitaya culture for our Region. He knows that the production of healthy seedlings, uniform and with more developed root system characteristics, are the most promising for the success in the implantation of a commercial fruit orchard. However, in the case of pitaya, our knowledge of propagation methods, material used, environment, substrate, fertilization and water supply are limited. In general, the crop is very easy to "pick up", developing satisfactorily when growing on substrates with good humidity, texture, porosity and with adequate nutrients. Without major difficulties, the producer manages to produce his seedlings and make his orchard in a short time. Therefore, this study aimed to evaluate the effect of substrates and irrigation frequencies on the growth of pitaya seedlings.

\section{MATERIALAND METHODS}

\section{Study area}

The experiment was conducted from January to May 2017 at the Universidade Federal Rural da Amazônia, Capitão Poço (UFRA-CCP), Pará, Brazil (014ㄹ 473 S $47^{\circ} 032343 \mathrm{~W}, 73 \mathrm{~m}$ above sea level) (Figure 1). Plants were grown in a greenhouse $(16 \times 30 \mathrm{~m})$ covered with a plastic film $(200 \mu \mathrm{m})$, without shading. In the study area, the temperature ranges from 25.7 to $26.9^{\circ} \mathrm{C}$, with an annual average temperature of $26.2{ }^{\circ} \mathrm{C}$ (Silva et al. 2011). Throughout the study period, the average temperature inside the greenhouse was $32.3 \pm 3.85^{\circ} \mathrm{C}$; and the relative humidity, 72\% (Termo-Higrometro Digital, JProlab, São José dos Pinhas, PR, Brazil).

\section{Characteristics of the propagation material}

Pitaya plants were produced from $H$. costaricensis cuttings. The propagation material was taken from the primary cladodes (main stems) of different 2-year-old plants from the orchard of UFRA-CCP. The cladodes were $25 \mathrm{~cm}$ long, as recommended by Moreira et al. (2017).

The cleaning and sterilization of the cladode was carried out with running water, and a solution of water + hypochloride $(100 \mathrm{~mL}$ to $10 \mathrm{~mL})$, in the proportion of one tablespoon of bleach for each liter of water. The propagating parts were previously cleaned and sterilized before planting. Immersed in hypochloride solution, in order to reduce deteriorating microbial activity in the material. The same was done with tools in the cutting process. The cuttings were fixed to the substrates right after the treatment.

According to Cunha \& Reinhardt (2004), in some fruit trees, as in the case of pineapples, the process of curing the seedlings to be used is carried out. This process aims to heal the wound that occurs when the propagating material is detached from the plant, in addition to reducing the risk of rotting, especially in periods of high humidity. However, the propagative material, cladodes, in our experiment, was not subjected to healing.

\section{Experimental design}

A completely randomized $3 \times 7$ factorial design with four replicates was used. Three types of substrates ( $\mathrm{S} 1$, $\mathrm{S} 2$, and S3) and seven irrigation frequencies were tested $(24,48,72,96,120,144$, and $168 \mathrm{~h})$, totaling 84 experimental units.

\section{Substrate}

The substrates used to produce rooted cuttings are described in Table 1. S1 and S2 were subjected to chemical and texture analysis (Table 2). Water holding capacity (WHC) was determined for all substrates. Polyethylene bags $\left(15 \times 25 \mathrm{~cm} ; 4.416 \mathrm{dm}^{3}\right)$ were filled with substrates and irrigated until saturation $24 \mathrm{~h}$ before the cladodes were planted.

\section{Irrigation management}

Irrigation was performed manually. The volume of water was determined on the basis of the WHC of each substrate, as shown in Eq. (1):

$\mathrm{WHC}(\mathrm{mm})=\frac{\mathrm{FC}-\mathrm{PWP}}{10} \times d \times z \times f$

where FC is the field capacity (\%), PWP is the permanent wilting point $(\%), d$ is the soil density $\left(\mathrm{g} \mathrm{cm}^{-3}\right), z$ is the actual root length $(\mathrm{cm})$, and $f$ is the soil water availability factor (dimensionless).

As estimated using Eq. (1) and recommended by Bernardo et al. (2006), $100 \mathrm{~mL}$ of drinking water was used for each substrate at each irrigation interval (Table 3). The first irrigation was performed $24 \mathrm{~h}$ after planting. The irrigation frequencies tested in this study were $24,48,72$, $96,120,144$, and $168 \mathrm{~h}$.

\section{Evaluation parameters}

The primary cladodes of the plants were collected and analyzed for cladode diameter variation, xylem diameter,

Rev. Ceres, Viçosa, v. 68, n.4, p. 276-284, jul/aug, 2021 
cladode fresh matter, cladode dry matter, and cladode volume. The following shoot parameters were determined: shoot length, shoot diameter, shoot fresh matter, shoot dry matter, budding volume, and number of areoles. The primary root length, primary root diameter, root fresh matter, root dry matter, and root volume were also determined.

The cladode diameter variation was estimated by the difference in the diameter of the cladode at the beginning and the end of the experiment (final diameter). A digital caliper was used to measure the diameter at the stem base. Shoot length and diameter were measured every five days after sprouting. Values less than $0.5 \mathrm{~cm}$ were not considered.

At the end of the experiment (132 days after planting), the plant material was collected by destructive harvesting.
The cladode, shoots, and roots were separated and analyzed at the laboratory. Fresh weight of the plant material was measured on a 0.0001- precision scale (AY220, Shimadzu, Kyoto, Japan). Dry matter was determined by placing samples in kraft paper bags and in an oven at 70 ${ }^{\circ} \mathrm{C}$ for drying until reaching constant matter. Volume was measured by soaking the samples in a test pot filled with water and calculating the difference between the volume of water before and after sample immersion.

Shoot parameters were determined only for plants that were grown in S1 and S2, as plants grown in S3 did not sprout. The other variables were determined for all plants.

\section{Statistical analysis}

The Shapiro-Wilk (1965) and Bartlett's tests (1937) were used to assess the data normality and homogeneity

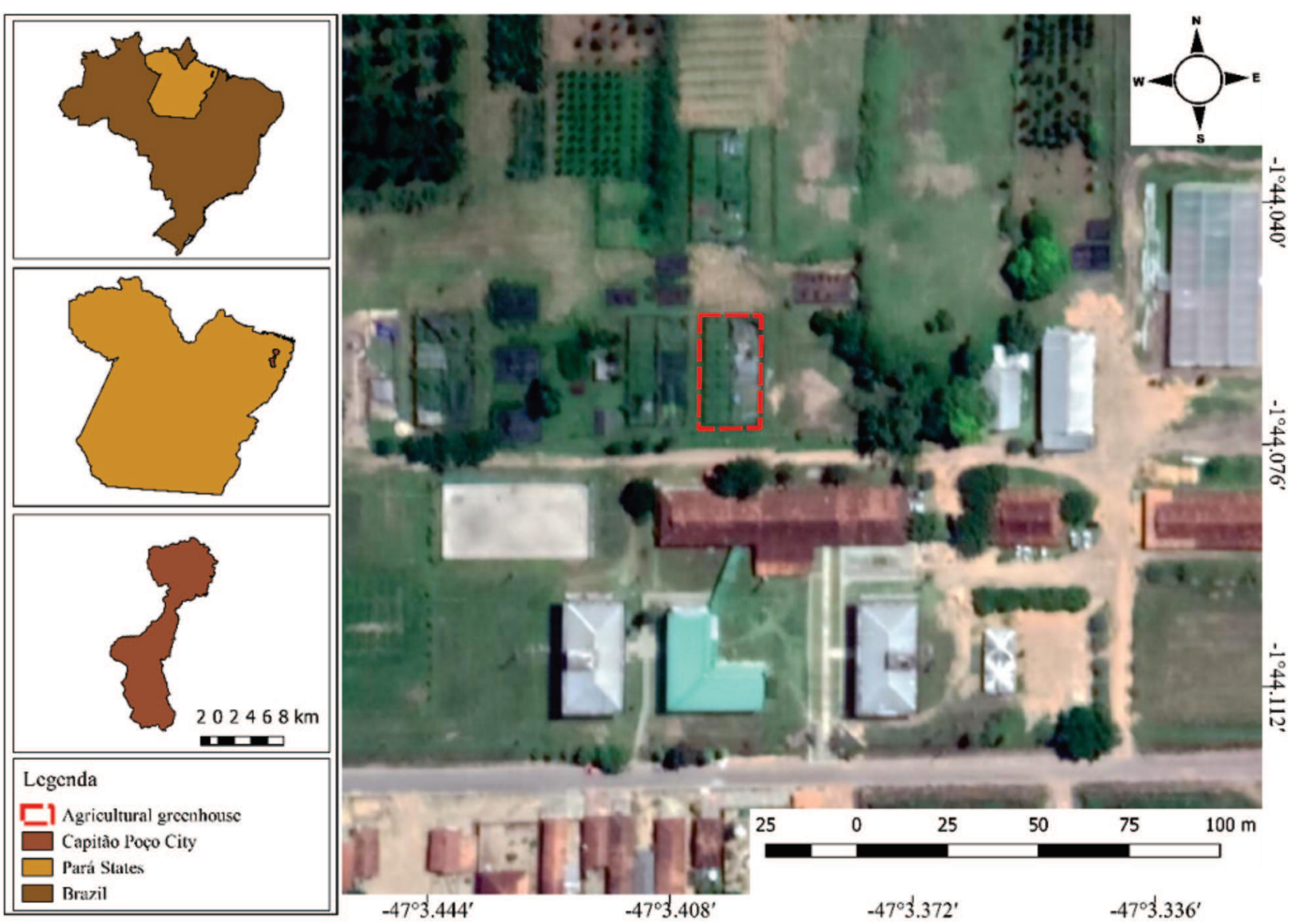

Figure 1: Location map of the study area showing the state of Pará (Brazil) and the municipality of Capitão Poço, where the experiments were conducted.

Table 1: Description of soil substrates used in this experiment

\begin{tabular}{lll}
\hline Substrate & \multicolumn{1}{c}{ Composition } & \multicolumn{1}{c}{ Characteristics } \\
\hline S1 & Potting soil & Nutrient-rich sandy soil containing carbonized organic residues \\
S2* & Potting soil, cattle manure, & A 3:1:1 mixture of each component. \\
S3 & and wood shavings & \\
\hline
\end{tabular}

* Prepared 30 days before use.

Rev. Ceres, Viçosa, v. 68, n.4, p. 276-284, jul/aug, 2021 
of variances $(p>0.05)$. Analysis of variance (ANOVA) was performed, and Scott-Knott's test was used to compare means at $p<0.05$, when necessary. Analyses were carried out using AgroEstat software (Barbosa \& Maldonado Junior, 2015) and R Core Team (2017).

Shoot length, shoot fresh matter, shoot dry matter, and budding volume were normalized using Box-Cox transformation (1964) using the log-likelihood function because of the heterogeneity of data.

Table 2: Chemical and texture characteristics of soil substrates S1 (potting soil) and S2 (3:1:1 mixture of potting soil, cattle manure, and wood shavings)

\begin{tabular}{|c|c|c|}
\hline Variable & S1 & $\mathbf{S} 2$ \\
\hline $\mathrm{pH}-\mathrm{CaCl}_{2}$ & 5.8 & 6.6 \\
\hline $\mathrm{OM}\left(\mathrm{g} \mathrm{kg}^{-1}\right)$ & 12.0 & 35.0 \\
\hline $\mathrm{Ca}\left(\mathrm{cmol}_{\mathrm{c}} \mathrm{dm}^{-3}\right)$ & 2.8 & 2.7 \\
\hline $\mathrm{Mg}\left(\mathrm{cmol}_{\mathrm{c}} \mathrm{dm}^{-3}\right)$ & 0.7 & 0.9 \\
\hline $\mathrm{Al}\left(\mathrm{cmol}_{\mathrm{c}} \mathrm{dm}^{-3}\right)$ & 0.00 & 0.00 \\
\hline $\mathrm{H}+\mathrm{Al}\left(\mathrm{cmol}_{\mathrm{c}} \mathrm{dm}^{-3}\right)$ & 1.8 & 1.5 \\
\hline $\mathrm{CEC}\left(\mathrm{cmol}_{\mathrm{c}} \mathrm{dm}^{-3}\right)$ & 5.49 & 5.54 \\
\hline $\mathrm{K}\left(\mathrm{cmol}_{\mathrm{c}} \mathrm{dm}^{-3}\right)$ & 0.194 & 0.440 \\
\hline $\mathrm{P}_{\mathrm{av}}\left(\mathrm{mg} \mathrm{dm}^{-3}\right)$ & 43 & 180 \\
\hline $\mathrm{K}\left(\mathrm{mg} \mathrm{dm}^{-3}\right)$ & 76 & 172 \\
\hline $\mathrm{Na}\left(\mathrm{mg} \mathrm{dm}^{-3}\right)$ & 2 & 1 \\
\hline $\mathrm{S}\left(\mathrm{mg} \mathrm{dm} \mathrm{m}^{-3}\right)$ & 4 & 4 \\
\hline $\mathrm{B}\left(\mathrm{mg} \mathrm{dm}^{-3}\right)$ & 0.1 & 0.2 \\
\hline $\mathrm{Cu}\left(\mathrm{mg} \mathrm{dm}^{-3}\right)$ & 2.3 & 2.3 \\
\hline $\mathrm{Fe}\left(\mathrm{mg} \mathrm{dm}^{-3}\right)$ & 122 & 63 \\
\hline $\operatorname{Mn}\left(\mathrm{mg} \mathrm{dm}^{-3}\right)$ & 34 & 34 \\
\hline $\mathrm{Zn}\left(\mathrm{mg} \mathrm{dm}^{-3}\right)$ & 2.3 & 1.6 \\
\hline $\mathrm{Ca} / \mathrm{Mg}(\%)$ & 4.0 & 3.0 \\
\hline $\mathrm{Al}_{\text {sat }}(\%)$ & 0.0 & 0 \\
\hline $\mathrm{V}(\%)$ & 67 & 73 \\
\hline $\mathrm{Ca} / \mathrm{CEC}(\%)$ & 50.9 & 49.1 \\
\hline $\mathrm{Mg} / \mathrm{CEC}(\%)$ & 12.7 & 16.4 \\
\hline$(\mathrm{H}+\mathrm{Al}) / \mathrm{CEC}(\%)$ & 32.7 & 27.3 \\
\hline $\mathrm{K} / \mathrm{CEC}(\%)$ & 3.5 & 8.0 \\
\hline Clay $\left(\mathrm{g} \mathrm{kg}^{-1}\right)$ & 100.0 & 80.0 \\
\hline Silt $\left(\mathrm{g} \mathrm{kg}^{-1}\right)$ & 60.0 & 30.0 \\
\hline Sand $\left(\mathrm{g} \mathrm{kg}^{-1}\right)$ & 840.0 & 890.0 \\
\hline
\end{tabular}

Abbreviations: OM: organic matter; Ca: calcium; Mg: magnesium; $\mathrm{Al}$ : aluminum; H: hydrogen; CEC: cation-exchange capacity; K: potassium; $\mathrm{P}_{\mathrm{av}}$ : available phosphorus; Na: sodium; $\mathrm{S}$ : sulfur; B: boron; $\mathrm{Cu}$ : copper; $\mathrm{Fe}$ : iron; $\mathrm{Mn}$ : manganese; $\mathrm{Zn}$ : zinc; $\mathrm{Al}_{\mathrm{sat}}$ : aluminum saturation; and V: base saturation.

\section{RESULTS AND DISCUSSION}

Tables 4 and 5 show the ANOVA results for all the parameters evaluated. Shoot parameters (shoot length, shoot fresh matter, shoot dry matter, budding volume, and number of areoles) were analyzed only in plants grown in S1 (potting soil) and S2 (a mixture of potting soil, cattle manure, and wood shavings). Plants grown in S3 (washed sand) did not sprout, showing that washed sand does not provide adequate conditions for the formation of new cladodes. However, plants showed good root formation in S3. Therefore, it is recommended to root the cuttings in sand and subsequently transplant them to a substrate with good nutrient availability (such as S1 and S2). Moreira et al. (2015) observed that washed sand was not suitable for Schizolobium parahyba (Vell.) S. F. Blake seedling production. Sand is an inert material with low nutrient concentration. Nevertheless, this substrate has good physical properties, such as low density and high porosity, which creates a favorable environment for root development.

Substrate had a significant effect on root fresh matter, root dry matter, primary root length, primary root diameter, root volume, primary cladode volume, primary cladodes fresh matter, and primary cladode diameter variation but not on cladode dry matter and xylem diameter (Table 4). Because of differences in aeration, water retention, fertility, and organic matter content between substrates, root parameters varied greatly. Silva et al. (2006) reported that different substrates had different effects on the root fresh matter of purple pitaya. Galvão et al. (2016) observed that the use of sand, soil, or a combination of both had significant effects on the root fresh and dry matter of white-fleshed red pitaya (H. undatus). In the current study, the type of the substrate also significantly influenced shoot dry matter, budding volume, and number of areoles (Table 5).

Irrigation frequency had a significant effect $(p<0.01)$ on primary cladode volume, primary cladodes fresh matter, root dry matter, and primary root length. The interaction effect of substrate and irrigation frequency was significant for root dry matter and primary root length (Table 4). Moreira et al. (2018) observed similar results. The authors reported that irrigation frequency influenced pitaya plant

Table 3: Description of the physical characteristics of the soil used in this experiment

\begin{tabular}{|c|c|c|c|c|c|}
\hline \multirow{2}{*}{ Substrate } & \multirow{2}{*}{ Composition } & $\theta_{\mathrm{FC}}(100 \mathrm{kPa})$ & $\theta_{\mathrm{WP}}(1500 \mathrm{kPa})$ & \multirow{2}{*}{$\frac{\mathrm{SD}}{\mathrm{g} \mathrm{cm}^{-3}}$} & \multirow{2}{*}{$\begin{array}{c}\begin{array}{c}\text { Amount } \\
\text { of irrigation }\end{array} \\
\mathrm{mm}\end{array}$} \\
\hline & & \multicolumn{2}{|c|}{$(\%)$} & & \\
\hline S1 & $\begin{array}{l}\text { Potting soil } \\
\end{array}$ & 17.82 & 7.13 & 1.20 & 13.48 \\
\hline $\mathrm{S} 2 *$ & Potting soil, cattle manure, and wood shavings & 7.57 & 1.48 & 1.93 & 13.50 \\
\hline S3 & Washed sand & 10 & 3.2 & 1.59 & 14.85 \\
\hline
\end{tabular}

$\theta_{\mathrm{FC}}=$ soil water content at field capacity at $100 \mathrm{kPa} ; \theta_{\mathrm{WP}}=$ soil water content at wilting point at $1500 \mathrm{kPa} ; \mathrm{Sd}=$ soil bulk density 
height, number of cladodes, primary cladode length, and primary cladode diameter.

The effect of irrigation frequency $\times$ substrate was significant $(p<0.01)$ for all shoot parameters (number of areoles and shoot length, diameter, fresh matter, dry matter, and volume), demonstrating the importance of these conditions for shoot development (Table 5).
Pitaya plants grown in S3 showed the lowest values for all cladode parameters analyzed (primary cladode volume, fresh matter, and diameter variation). This result was expected because, despite the good aeration and texture characteristics of S3, this substrate has poor nutrient and water retention, which limits plant growth in periods of high nutrient and

Table 4: Analysis of variance for primary cladode volume (PCV), primary cladodes fresh matter (PCFM), primary cladode dry matter (CDM), primary cladode diameter variation (CDV), primary cladode xylem diameter (XD), root fresh matter (RFM), root dry matter (RDM), root length (RL), root diameter (RD), and root volume (RV) of pitaya plants grown in different substrates (SB) under different irrigation frequencies (IF)

\begin{tabular}{|c|c|c|c|c|c|}
\hline Source of variation & SB & IF & $\mathrm{SB} \times \mathbf{I F}$ & Residual & CV (\%) \\
\hline $\mathrm{PCV}\left(\mathrm{cm}^{3}\right.$ plant $\left.^{-1}\right)$ & $9076.75 * *$ & $2424.35 * *$ & $438.25^{\mathrm{ns}}$ & 532.29 & 19.29 \\
\hline PCFM (g plant ${ }^{-1}$ ) & $8422.00 * *$ & $2418.52 * *$ & $420.13^{\mathrm{ns}}$ & 450.73 & 17.60 \\
\hline CDM (g plant $\left.{ }^{-1}\right)$ & $2.03^{\mathrm{ns}}$ & $2.10^{\mathrm{ns}}$ & $3.63^{\mathrm{ns}}$ & 3.47 & 18.08 \\
\hline $\mathrm{CDV}\left(\mathrm{mm}\right.$ plant $\left.^{-1}\right)$ & $10.92 *$ & $8.06^{\mathrm{ns}}$ & $2.71^{\mathrm{ns}}$ & 2.59 & 48.66 \\
\hline $\mathrm{XD}\left(\mathrm{mm}\right.$ plant $\left.^{-1}\right)$ & $0.89^{\mathrm{ns}}$ & $0.18^{\mathrm{ns}}$ & $0.64^{\mathrm{ns}}$ & 1.00 & 15.97 \\
\hline RFM $\left(\right.$ g plant $\left.^{-1}\right)$ & $816.62 * *$ & $13.08^{\mathrm{ns}}$ & $10.66^{\mathrm{ns}}$ & 7.98 & 24.88 \\
\hline RDM (g plant $\left.{ }^{-1}\right)$ & $38.65 * *$ & $3.82 * *$ & $1.96^{*}$ & 1.02 & 23.38 \\
\hline PRL (cm plant $\left.{ }^{-1}\right)$ & $1574.36 * *$ & $220.42 * *$ & $139.45^{*}$ & 66.40 & 20.12 \\
\hline $\mathrm{RD}\left(\mathrm{mm}\right.$ plant $\left.^{-1}\right)$ & $5.38 * *$ & $0.77^{\mathrm{ns}}$ & $0.40^{\mathrm{ns}}$ & 0.68 & 22.15 \\
\hline $\mathrm{RV}\left(\mathrm{cm}^{3}\right.$ plant $\left.^{-1}\right)$ & $647.40 * *$ & $95.45^{\mathrm{ns}}$ & $89.27^{\mathrm{ns}}$ & 47.22 & 26.07 \\
\hline
\end{tabular}

* Significant at $p<0.05$;* Significant at $p<0.01$; ns: not significant by the $F$-test; CV: coefficient of variation. SB d.f. $=2$; IF d.f. $=6$; $\mathrm{SB} \times \mathrm{IF}$ d.f. $=12 ;$ treatment d.f. $=21$; residual d.f. $=63$.

Table 5: Analysis of variance for shoot length (SL), shoot diameter (SD), shoot fresh matter (SFM), shoot dry matter (SDM), budding volume $(\mathrm{BV})$, and number of areoles (NA) of pitaya plants grown in different substrates $(\mathrm{SB})$ under different irrigation frequencies (IF)

\begin{tabular}{|c|c|c|c|c|c|}
\hline Source of variation & SB & IF & $\mathbf{S B} \times \mathbf{I F}$ & Residual & $\mathrm{CV}(\%)$ \\
\hline SL (cm plant $\left.{ }^{-1}\right)$ & $37.08^{\mathrm{ns}}$ & $61.37 * *$ & $39.14 * *$ & 9.70 & 39.77 \\
\hline $\mathrm{SD}\left(\mathrm{mm}\right.$ plant $\left.^{-1}\right)$ & $2457.88^{\mathrm{ns}}$ & $3447.42 * *$ & $3075.64 * *$ & 735.05 & 52.28 \\
\hline SFM $\left(\right.$ g plant $\left.^{-1}\right)$ & $15.57^{\mathrm{ns}}$ & $30.18 * *$ & $19.53 * *$ & 5.94 & 50.06 \\
\hline SDM $\left(g_{\text {plant }}^{-1}\right)$ & $2.18^{*}$ & $1.43 * *$ & $1.30 * *$ & 0.39 & 34.22 \\
\hline $\mathrm{BV}\left(\mathrm{cm}^{3}\right.$ plant $\left.^{-1}\right)$ & $1.18^{*}$ & $0.61 * *$ & $0.66 * *$ & 0.19 & 28.01 \\
\hline NA (n plant $\left.{ }^{-1}\right)$ & $1020.02 *$ & $1679.88 * *$ & $873.77 * *$ & 232.13 & 43.07 \\
\hline
\end{tabular}

* Significant at $p<0.05 ; * *$ Significant at $p<0.01$; ns: not significant by the $F$-test; CV: coefficient of variation. SB d.f. $=1$; IF d.f. $=6$; $\mathrm{SB} \times \mathrm{IF}$ d.f. $=6$; treatment d.f. $=14$; residual d.f. $=42$.

Table 6: Mean root dry matter and primary root length of pitaya (Hylocereus costaricensis) under different soil substrates and irrigation frequencies

\begin{tabular}{|c|c|c|c|c|c|c|}
\hline \multirow{3}{*}{$\begin{array}{l}\text { Irrigation } \\
\text { frequency }\end{array}$} & \multicolumn{3}{|c|}{ Root dry matter } & \multicolumn{3}{|c|}{ Primary root length } \\
\hline & \multicolumn{3}{|c|}{ g plant $^{-1}$} & \multicolumn{3}{|c|}{ cm plant $^{-1}$} \\
\hline & S1 & S2 & S3 & S1 & S2 & S3 \\
\hline $24 \mathrm{~h}$ & $3.87 \mathrm{~b} \mathrm{~A}$ & 2.88 a A & $4.11 \mathrm{~b} \mathrm{~A}$ & $35.03 \mathrm{a} \mathrm{B}$ & 43.10 a B & 64.83 a A \\
\hline $48 \mathrm{~h}$ & $3.63 \mathrm{~b} \mathrm{~A}$ & 3.17 a A & $3.66 \mathrm{~b} \mathrm{~A}$ & 33.48 a A & $41.93 \mathrm{a} \mathrm{A}$ & $44.43 \mathrm{ab} \mathrm{A}$ \\
\hline $72 \mathrm{~h}$ & $5.75 \mathrm{ab} A$ & $2.88 \mathrm{a} \mathrm{A}$ & $4.47 \mathrm{ab} \mathrm{AB}$ & $41.80 \mathrm{a} \mathrm{A}$ & $40.10 \mathrm{ab} \mathrm{A}$ & $52.40 \mathrm{ab} \mathrm{A}$ \\
\hline $96 \mathrm{~h}$ & 6.20 a A & 3.38 a B & $4.97 \mathrm{ab} \mathrm{AB}$ & 36.43 a A & $33.08 \mathrm{ab} \mathrm{A}$ & $44.75 \mathrm{ab} A$ \\
\hline $120 \mathrm{~h}$ & $5.73 \mathrm{ab} A$ & 2.98 a B & $4.45 \mathrm{ab} \mathrm{AB}$ & $41.35 \mathrm{a} \mathrm{A}$ & $32.95 \mathrm{ab} A$ & $45.83 \mathrm{ab} \mathrm{A}$ \\
\hline $144 \mathrm{~h}$ & $5.48 \mathrm{ab} \mathrm{A}$ & 2.59 a B & 6.35 a A & 33.30 a B & 22.95 b B & $50.05 \mathrm{ab} \mathrm{A}$ \\
\hline $168 \mathrm{~h}$ & $6.18 \mathrm{a} A$ & 3.17 a B & $4.96 \mathrm{ab} \mathrm{A}$ & $39.10 \mathrm{a} \mathrm{A}$ & $32.25 \mathrm{ab} \mathrm{A}$ & $41.23 \mathrm{~b} \mathrm{~A}$ \\
\hline
\end{tabular}

Note: Plants grown in potting soil (S1), a mixture of potting soil, cattle manure, and wood shavings (S2), or washed sand (S3). Means followed by different lower-case letters (in the columns) or upper-case letters (on the rows) are significantly different according to ScottKnott test $(p<0.05)$. 
water demand (Figure 2). These findings are corroborated by the observations of Alves et al. (2018), who found that sandy soils led to lower plant height and stem diameter in Schizolobium parahyba var. amazonicum seedlings. In pitaya cultivation, high primary cladode volumes are of great importance, as plants with larger cladodes can support a larger canopy and are likely to receive more sunlight, resulting in increased growth and yield. In the current study, substrates containing higher levels of organic matter, particularly S2, provided the best nutrient supply and moisture retention for plant growth (Figure 2).

The results of root development (Figure 2) were not as straightforward to interpret. S1 led to the highest root volume, $\mathrm{S} 2$ to the highest primary root diameter, and S3 to the highest root fresh matter. Overall, it was
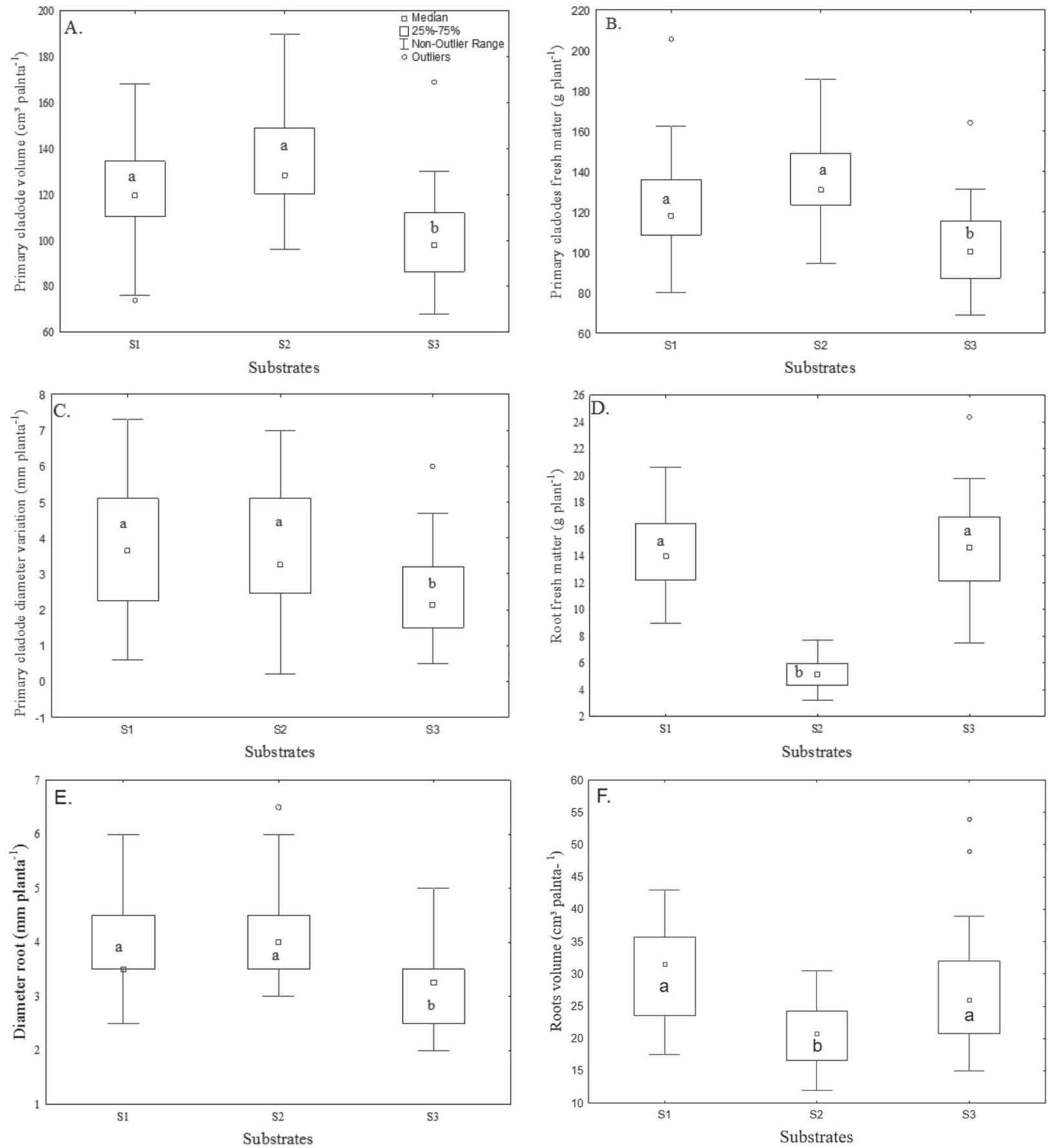

*Different letters denote significant $(p<0.05)$ differences between means according to Scott-Knott test.

Figure 2: Primary cladode volume (A), Primary cladodes fresh matter (B), primary cladode diameter variation (C), root fresh matter (D), root diameter (E) and root volume (F) of pitaya plants grown in different substrates. Plants grown in potting soil (S1), a mixture of potting soil, cattle manure, and wood shavings (S2), or washed sand (S3). 
found that substrates containing higher levels of nutrients and organic matter improved all root parameters, except root fresh matter. Galvão et al. (2016), when analyzing plant growth in different substrates, concluded that soil and a mixture of sand and soil led
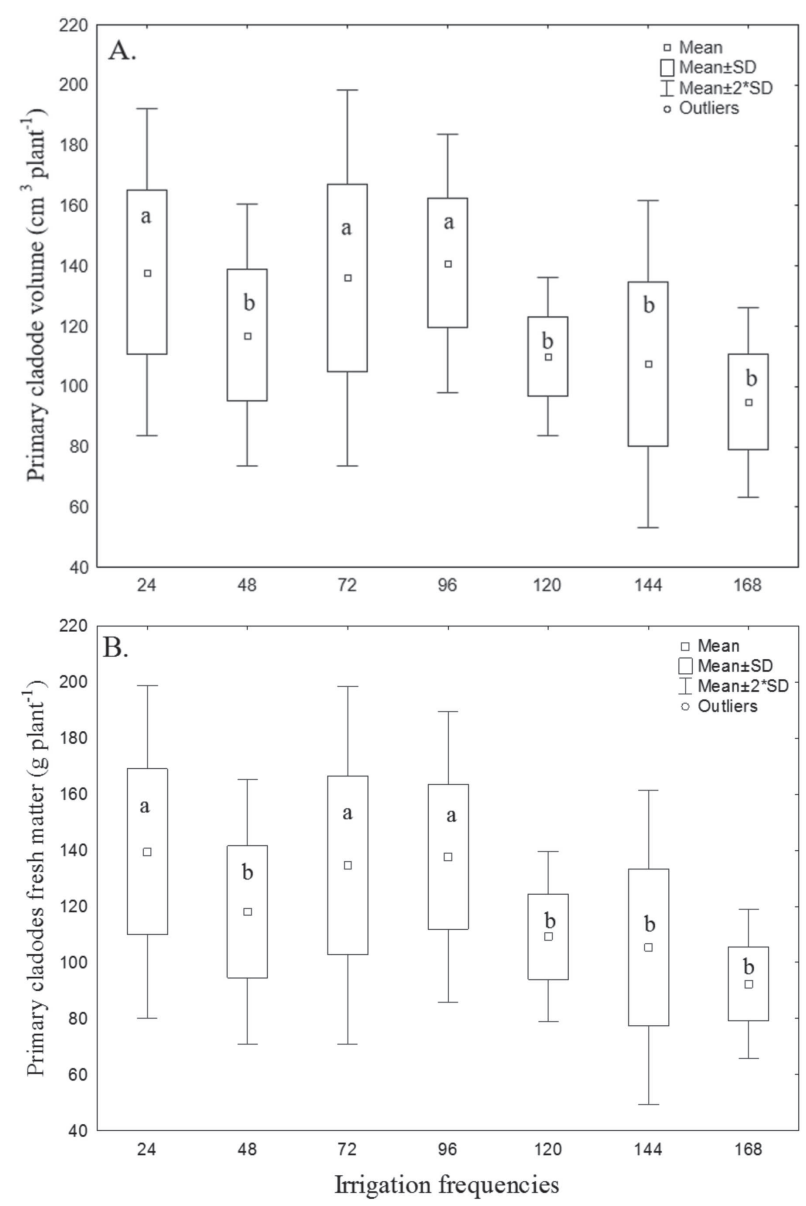

*Different letters denote significant $(p<0.05)$ differences between means according to Scott-Knott test

Figure 3: Primary cladode volume (A) and primary cladodes fresh matter (B) of pitaya plants under different irrigation frequencies. to higher shoot fresh matter, shoot dry matter, and root dry matter, whereas sand resulted in higher root fresh matter. In line with these data, Santos et al. (2010a) reported that washed sand led to higher root fresh matter and that substrates containing composted cattle manure (rich in organic matter) produced plants with higher shoot fresh matter.

In general, pitaya cladodes and roots developed better in S1 and S2 than in S3, probably because of the greater availability of organic matter. An adequate substrate must have sufficient water retention to prevent tissue desiccation at the stem base and an adequate porosity to maintain constant oxygen supply to the roots (Fachinello et al. 2005). A well-developed root system is another key factor for plant growth so that it improves water and nutrient absorption by allowing plants to make good use of the volume of substrate available to them (Almeida et al. 2017).

The 48-h irrigation interval produced the best results for primary cladode volume and fresh matter (Figure 3). Because pitaya uses CAM photosynthesis, it develops well even when water supply is not frequent. However, long irrigation intervals might hamper development, consequently affecting fruit production. Moreira et al. (2018) obtained similar results: pitaya plants irrigated every three days showed greater primary cladode length and diameter.

High root dry matter was observed in plants grown in S3 under a 144-h irrigation interval (Table 6). Pitaya root system responds well to large irrigation intervals because the lack of water stimulates the plant to develop deeper roots. Furthermore, S3 was important for initial root development in pitaya cuttings. Santos et al. (2010b) observed that root matter and primary root length were higher in plants grown in sand and soil, as the species is well adapted to sandy soils. A combination of S3 and daily irrigation $(24 \mathrm{~h})$ was the most suitable for primary root length development (Table 6).

Table 7: Mean shoot length, shoot diameter, and budding volume of pitaya under different soil substrates and irrigation frequencies

\begin{tabular}{|c|c|c|c|c|c|c|}
\hline \multirow{3}{*}{$\begin{array}{l}\text { Irrigation } \\
\text { frequency }\end{array}$} & \multirow{2}{*}{\multicolumn{2}{|c|}{$\begin{array}{c}\text { Shoot length } \\
\text { cm plant }^{-1}\end{array}$}} & \multicolumn{2}{|c|}{ Shoot diameter } & \multicolumn{2}{|c|}{ Budding volume } \\
\hline & & & $\mathbf{m m}$ & $\mathrm{ant}^{-1}$ & & \\
\hline & S1 & S2 & S1 & S2 & S1 & S2 \\
\hline$\overline{24 \mathrm{~h}}$ & $7.52 \mathrm{~b} \mathrm{~A}$ & $9.92 \mathrm{ab} \mathrm{A}$ & $45.88 \mathrm{~b} \mathrm{~A}$ & $55.00 \mathrm{abc} \mathrm{A}$ & $1.39 \mathrm{ab} \mathrm{A}$ & $1.73 \mathrm{ab} \mathrm{A}$ \\
\hline $48 \mathrm{~h}$ & $9.33 \mathrm{ab} \mathrm{A}$ & 10.79 a A & $63.75 \mathrm{ab} A$ & 86.25 a A & $1.67 \mathrm{ab} \mathrm{A}$ & $1.85 \mathrm{a} \mathrm{A}$ \\
\hline $72 \mathrm{~h}$ & 15.37 a A & $8.83 \mathrm{ab} \mathrm{B}$ & $113.63 \mathrm{a} \mathrm{A}$ & $49.00 \mathrm{abc} B$ & $2.32 \mathrm{a} \mathrm{A}$ & $1.56 \mathrm{ab} B$ \\
\hline $96 \mathrm{~h}$ & $6.77 \mathrm{~b} \mathrm{~A}$ & 10.15 a A & $43.38 \mathrm{~b} \mathrm{~A}$ & $71.75 \mathrm{ab} A$ & $1.58 \mathrm{ab} \mathrm{A}$ & $1.82 \mathrm{a} \mathrm{A}$ \\
\hline $120 \mathrm{~h}$ & $9.10 \mathrm{ab} \mathrm{A}$ & $1.45 \mathrm{c} \mathrm{B}$ & $63.63 \mathrm{ab} \mathrm{A}$ & $4.25 \mathrm{c} \mathrm{B}$ & $1.95 \mathrm{ab} \mathrm{A}$ & $0.80 \mathrm{~b} \mathrm{~B}$ \\
\hline $144 \mathrm{~h}$ & $5.19 \mathrm{~b} \mathrm{~A}$ & $4.62 \mathrm{abc} \mathrm{A}$ & $22.88 \mathrm{~b} \mathrm{~A}$ & $30.25 \mathrm{abc} \mathrm{A}$ & $1.30 \mathrm{~b} \mathrm{~A}$ & $1.03 \mathrm{ab} \mathrm{A}$ \\
\hline $168 \mathrm{~h}$ & $7.21 \mathrm{~b} \mathrm{~A}$ & $3.33 \mathrm{bc} \mathrm{A}$ & $56.25 \mathrm{ab} A$ & $20.13 \mathrm{bc} \mathrm{A}$ & $1.61 \mathrm{ab} \mathrm{A}$ & $1.00 \mathrm{ab} \mathrm{A}$ \\
\hline
\end{tabular}

Note: Plants grown in potting soil (S1), a mixture of potting soil, cattle manure, and wood shavings (S2), or washed sand (S3); Means followed by different lower-case letters (in the columns) or upper-case letters (on the rows) are significantly different according to ScottKnott test $(p<0.05)$. 
Table 8: Mean shoot fresh matter, shoot dry matter, and number of areoles of pitaya under different soil substrates and irrigation frequencies

\begin{tabular}{|c|c|c|c|c|c|c|}
\hline \multirow{3}{*}{$\begin{array}{l}\text { Irrigation } \\
\text { frequency }\end{array}$} & \multicolumn{2}{|c|}{ Shoot fresh matter } & \multicolumn{2}{|c|}{ Shoot dry matter } & \multicolumn{2}{|c|}{ Number of areoles } \\
\hline & \multicolumn{4}{|c|}{ g plant $^{-1}$} & \multicolumn{2}{|c|}{ n plant ${ }^{-1}$} \\
\hline & S1 & S2 & S1 & S2 & S1 & S2 \\
\hline $24 \mathrm{~h}$ & $43.26 \mathrm{~b} \mathrm{~A}$ & 79.08 abc A & $2.51 \mathrm{a} \mathrm{A}$ & $4.47 \mathrm{a} \mathrm{A}$ & $32.00 \mathrm{~b} \mathrm{~A}$ & $41.25 \mathrm{ab} A$ \\
\hline $48 \mathrm{~h}$ & $74.81 \mathrm{ab} \mathrm{A}$ & 110.38 a A & $4.82 \mathrm{a} \mathrm{A}$ & 6.95 a A & $47.75 \mathrm{ab} \mathrm{A}$ & $50.75 \mathrm{a} \mathrm{A}$ \\
\hline $72 \mathrm{~h}$ & $160.03 \mathrm{a} \mathrm{A}$ & $67.41 \mathrm{abc} A$ & $11.13 \mathrm{a} \mathrm{A}$ & $3.51 \mathrm{ab} A$ & $76.00 \mathrm{a} A$ & $37.75 \mathrm{abc} B$ \\
\hline $96 \mathrm{~h}$ & $49.66 \mathrm{~b} \mathrm{~A}$ & $94.51 \mathrm{ab} A$ & $4.05 \mathrm{a} \mathrm{A}$ & 5.74 a A & $30.00 \mathrm{~b} \mathrm{~A}$ & $46.00 \mathrm{ab} \mathrm{A}$ \\
\hline $120 \mathrm{~h}$ & $78.88 \mathrm{ab} A$ & $0.76 \mathrm{~d} \mathrm{~B}$ & 7.04 a A & 0.02 b B & $41.25 \mathrm{~b} \mathrm{~A}$ & $7.00 \mathrm{c} \mathrm{B}$ \\
\hline $144 \mathrm{~h}$ & $23.80 \mathrm{~b} \mathrm{~A}$ & $14.79 \mathrm{~cd} \mathrm{~A}$ & $2.50 \mathrm{a} \mathrm{A}$ & $1.11 \mathrm{ab} \mathrm{A}$ & $17.25 \mathrm{~b} \mathrm{~A}$ & $13.00 \mathrm{bc} \mathrm{A}$ \\
\hline $168 \mathrm{~h}$ & $52.92 \mathrm{~b} \mathrm{~A}$ & $11.52 \mathrm{bcd} A$ & 4.56 a A & $0.76 \mathrm{ab} A$ & $33.25 \mathrm{~b} \mathrm{~A}$ & $22.00 \mathrm{abc} \mathrm{A}$ \\
\hline
\end{tabular}

Note: Plants grown in potting soil (S1), a mixture of potting soil, cattle manure, and wood shavings (S2), or washed sand (S3). Means followed by different lower-case letters (in the columns) or upper-case letters (on the rows) are significantly different according to ScottKnott test $(p<0.05)$

The shoots of pitaya grown in S1 responded well to the 72-h irrigation interval (Tables 7 and 8), probably because of their CAM metabolism. These variables are of great importance for fruit production, as the aerial parts are responsible for photosynthetic processes. A larger surface implies greater light absorption, which contributes to sprouting. Moreira et al. (2018) concluded that a threeday irrigation frequency is the most adequate for the development of pitaya plants. Furthermore, substrate containing potting soil favored shoot development. In a study by Queiroz et al. (2015), the growth (shoots and root system) and yield of the cactus species Opuntia stricta did not increase with higher water availability.

The best substrates for producing pitaya from cuttings are those that are rich in organic matter; in the case of this study, S1 and S2. Pitaya does not need frequent irrigation because of its intrinsic characteristics, such as CAM photosynthesis, allowing for efficient use of water. Irrigation frequencies of 48 to $72 \mathrm{~h}$ can be used to achieve optimum results while complying with the precepts of rational use of water and energy.

\section{CONCLUSIONS}

Washed sand promoted the development of the root system of pitaya cuttings at initial stages but impaired shoot growth. The primary cladode and new cladodes showed increased growth in potting soil. The results showed that daily irrigation is not necessary for pitaya plants. Irrigation intervals of 48 to $72 \mathrm{~h}$ are recommended to produce cuttings.

\section{ACKNOWLEDGEMENTS, FINANCIAL SUPPORT AND FULL DISCLOSURE}

The authors thank the Brazilian National Council for Scientific and Technological Development (CNPq) and the Brazilian Federal Agency for Support and Evaluation of Graduate Education (CAPES) for the financial support.

The authors report that there is no conflict of interest.

\section{REFERENCES}

Almeida JPN, Leite GA, Mendonça V, Cunha PSCF, Arrais IG \& Tosta MS (2017) Concentrações de AIB e substratos no enraizamento e vigor de estacas lenhosas de cajaraneira. Revista Ciências Agrárias, 60:11-18.

Almeida OA, Silva SLF, Haroldo RD \& Correa CR (2002) Influência da irrigação no ciclo do abacaxizeiro cv. Pérola em área de Tabuleiro Costeiro. Revista Brasileira de Fruticultura, 24:431435 .

Alves JDN, Moreira WKO, Oliveira SS \& Silva RTL (2018) Substrates and irrigation frequencies in the development os seedlings of Schizolobium parahyba var. amazonicum. Jornal of Agricultural Science, 10:249-258.

Barbosa JC \& Maldonado Júnior W (2015) AgroEstat: sistema para análises estatísticas de ensaios agronômicos. Jaboticabal, UNESP. 396 pp.

Bartlett MS (1937) Properties of sufficiency and statistical tests. The Royal Society, 160:268-282.

Bernardo S, Soares AA \& Mantovani EC (2006) Manual de Irrigação. $8^{\text {th }}$ ed. Viçosa, Editora UFV. 625p.

Box GEP \& Cox DR (1964) An analysis of transformations. Journal of the Royal Statistical Society, 26:211-252.

Cunha GAP \& Reinhardt DHRC (2004) Manejo de mudas de abacaxi. Cruz das Almas, Embrapa. 4p. (Comunicado Técnico, 105).

Fachinello JC, Hoffmann A \& Nachtigal JC (2005) Propagação de plantas frutíferas. Brasília, Embrapa Informações Tecnológicas. $221 \mathrm{p}$.

Galvão EC, Ramos JD, Pio LAS, Laredo RR, Silva FOR \& Miranda JMS (2016) Substratos e ácido indol-3-butírico na produção de mudas de pitaia vermelha de polpa branca. Revista Ceres, 63:860867.

Junqueira KP, Faleiro FG, Bellon G, Junqueira NTV, Fonseca KG, Lima CA \& Santos EC (2010) Variabilidade genética de acessos de pitaya com diferentes níveis de produção por meio de marcadores RAPD. Revista Brasileira de Fruticultura, 32:840846.

Le Bellec F, Villant F \& Imbert E (2006) Pitahaya (Hylocereus spp.): a new crop, a market with a future. Fruits, 61:237-250.

Melo AS, Aguiar Netto AO, Dantas Neto J \& Brito MEB (2006) Desenvolvimento vegetativo, rendimento da fruta e otimização do abacaxizeiro cv. Pérola em diferentes níveis de irrigação. Ciência Rural, 36:93-98.

Rev. Ceres, Viçosa, v. 68, n.4, p. 276-284, jul/aug, 2021 
Mizrahi Y \& Nerd A (1999) Climbing and columnar cacti-new arid lands fruit crops. In: Janick J (Ed.) Perspective in new crops and new crops uses. Alexandria, ASHS. p.358-366.

Mizrahi Y, Nerd A \& Nobel OS (1996) Cacti as crops. Horticultural Review, 18:291-320.

Moreira AR, Souza FLB, Silva RTL, Oliveira RLL, Alonço AS, Neto CFO \& Sousa SKA (2017) Determinação do comprimento da estaca para a produção de mudas de pitaia (Hylocereus costaricensis) em ambiente protegido. Tecno-lógica, 21:41-45.

Moreira AR, Souza FLB, Silva RTL, Oliveira RLL, Alonço AS Souza LC \& Carpes DP (2018) Determinação do turno de rega para a produção de mudas de pitaya em ambiente protegido. Tecno-lógica, 22:73-77.

Moreira WKO, Alves JDN, Leão FAN, Oliveira SS \& Okumura RS (2015) Efeito de substratos no crescimento de mudas de guapuruvú (Schizolobium parahyba (VELL.) S. F. BLAKE). Enciclopédia Biosfera, 11:1067-1075.

Nerd A, Tel-Zur N \& Mizrahi Y (2002) Fruit of vine and columnar cacti. In: Nobel PS (Ed.) Cacti: biology and uses. Los Angeles,UCLA. p.254-262.

Nie Q, Gao GL, Fan QJ, Qiao G, Wen XP, Liu T, Peng ZJ \& Cai YQ (2015) Isolamento e caracterização de um gene catalase HuCAT3 de pitaya (Hylocereus undatus) e sua expressão sob estresse abiótico. Gene, 563:63-67.
Queiroz MG, Silva TGF, Zolnier S, Silva SMS, Lima LR \& Alves JO (2015) Características morfofisiológicas e produtividade de palma forrageira em diferentes lâminas de irrigação. Revista Brasileira de Engenharia Agrícola e Ambiental, 19:931-938.

R Core Team (2017) R: A language and environment for statistical computing. R Foundation for Statistical Computing, Vienna, Austria. Available at: 〈https://www.R-project.org/>. Accessed on: January $15^{\text {th }}, 2018$.

Santos CMG, Cerqueira RC, Fernandes LMS, Rodrigues JD \& Ono EO (2010a) Efeito de substratos e boro no enraizamento de estacas de pitaya. Revista Ceres, 57:795-802.

Santos CMG, Cerqueira RC, Fernandes LMS, Dourado FWN \& Ono EO (2010b) Substratos e regulador vegetal no enraizamento de estacas de pitaya. Revista Ciência Agronômica, 41:625-629.

Shapiro SS \& Wilk MB (1965) An analysis of variance test for normality (complete samples). Biometrika, 52:591-611.

Silva AG, Boiça Junior AL, Farias PRS \& Barbosa JC (2011) Infestação da mosca-negra-dos-citros em pomares de citros, em sistemas de plantio convencional e agroflorestal. Revista Brasileira de Fruticultura, 33:053-060.

Silva MTH, Martins ABG \& Andrade RA (2006) Enraizamento de estacas de pitaya vermelha em diferentes substratos. Revista Caatinga, 19:61-64 